Preface

\title{
Biologic Role of the Plasminogen-Plasmin System: Thrombolysis, Bleeding, and Beyond
}

\author{
Hau C. Kwaan, MD, FRCP ${ }^{1}$ Andrew P. Mazar, $\mathrm{PhD}^{2,3}$ \\ ${ }^{1}$ Division of Hematology/Oncology, Feinberg School of Medicine, \\ Northwestern University, Chicago, Illinois \\ ${ }^{2}$ Chemistry of Life Processes Institute, Northwestern University, \\ Evanston, Illinois \\ 3 Robert H. Lurie Comprehensive Cancer Center, Northwestern \\ University, Evanston, Illinois
}

Semin Thromb Hemost 2013;39:327-328.

In many modes of destroying life the blood is deprived of its power of coagulation, as happens in sudden death produced by many kinds of fits, by anger, electricity or lightning; or by a blow on the stomach, etc. In these cases we find the blood, after death, not only as fluid a state as in the living vessels, but it does not even coagulate when taken out of them

$$
\text { -John Hunter }{ }^{1}
$$

Since Morgagni ${ }^{2}$ and John Hunter ${ }^{1}$ observed postmortem fibrinolysis in the 18th century, our knowledge of fibrinolysis has evolved from viewing it as a means of dissolving fibrin clots to being an important component of many biologic processes. In the 1950s, fibrinolysis was recognized to be a system that regulates hemostasis. In the following decades, interests centered on the development of fibrinolytic compounds for use in thrombolytic therapy. Then, beginning in the early 1990s, components of the fibrinolytic system were found to be involved in both normal physiologic as well pathologic processes. This opened up new, previously unanticipated avenues of investigation in the biology of the fibrinolytic system. As such, the "fibrinolytic system" is now more commonly referred to as the "plasminogen-plasmin system" (P-P system). The P-P system, in addition to plasminogen, is composed of several plasminogen activators (urokinase plasminogen activator [uPA] and tissue plasminogen activator [tPA]), several plasminogen activator inhibitors (PAI-1 and PAI-2) and the inhibitor of plasmin ( $\alpha_{2}$-antiplasmin). In 1991, an issue of Seminars in Thrombosis \& Hemostasis was devoted to the "Cell Biology of Fibrinolysis." 3 In the ensuing 20 years, the field has expanded greatly, and it is time for our readers to get an update, which is presented herein.

This issue begins with reviews on the major components of the P-P system. These include a review by Miles and Parmer on recently discovered plasminogen receptors, ${ }^{4}$ an update on

Address for correspondence Hau C. Kwaan MD, FRCP, Division of Hematology/Oncology, 710 Fairbanks Court, Olson Pavilion, Room 8258, Chicago, IL 60611 (e-mail: h-kwaan@northwestern. edu). a role for the canonical plasminogen receptor, annexin $\mathrm{A} 2$, in diseases, ${ }^{5}$ followed by a molecular view of the uPA receptor (uPAR) by Ferraris and Sidenius. ${ }^{6}$ Another member of the P-P system that has a versatile role in biology and the pathogenesis of many diseases is PAI- 1 and its implication on various processes is expanding almost on a daily basis. A series of reviews on this emerging important therapeutic target follow. An update of our understanding of this molecule is given by Declerck and Gils. ${ }^{7}$ This is followed by a description of the more recently discovered inhibitor of plasmin and plasminogen activator, the thrombin activatable fibrinolytic inhibitor, which is discussed by Vercauteren et al. ${ }^{8}$

As PAI- 1 is now recognized to be of the key factors in pulmonary fibrosis, and so an account of this is provided by Tucker and Idell. ${ }^{9}$

Much recent work has been devoted to determine the importance of the P-P system in cancer. UPA, UPAR, and PAI1 have all been implicated in tumor progression, and expression of these various components is associated with poor prognosis in various cancer types. In particular, the UPAR is a key member in the complex interactions of this system that drive tumor progression. This is reviewed by Kwaan et al. ${ }^{10}$

The role of the P-P system is also emerging in various other diseases. The remaining parts of this issue therefore focus on these emerging roles of the P-P system, beginning with an article by Gando, ${ }^{11}$ which describes the role of fibrinolysis in patients with sepsis and trauma. A critical review of the tissueplasminogen activator, tPA, for intraventricular hemorrhage is then presented by Wong and Bailes ${ }^{12}$ and followed by a review from del Zoppo ${ }^{13}$ on the state of thrombolytic therapy for treating stroke. In the next article, Violi and Ferro ${ }^{14}$ review the role of increased fibrinolysis in the pathobiology of liver disease. Dhillon and Adams then discuss an important but often overlooked role for the fibrinolytic system in systemic lupus erythematosus. ${ }^{15}$ This represents just one example of
Issue Theme Biologic Role of the Plasminogen-Plasmin System: Thrombolysis, Bleeding, and Beyond; Guest Editors, Hau C. Kwaan, MD, FRCP, and Andrew P. Mazar, PhD.
Copyright @ 2013 by Thieme Medical Publishers, Inc., 333 Seventh Avenue, New York, NY 10001, USA. Tel: +1(212) 584-4662.
DOI http://dx.doi.org/ 10.1055/s-0033-1343616. ISSN 0094-6176. 
the potential role of the P-P system as well as dysregulated coagulation in autoimmune diseases and an area that probably deserves more attention from the translational community working in fibrinolysis and coagulation. Finally, this issue of Seminars in Thrombosis \& Hemostasis concludes with a series of three reviews on "applied" thrombolysis, two on catheterdirected thrombolysis for arterial and venous thrombosis by Wicky et $\mathrm{al}^{16}$ and Oklu and Wicky ${ }^{17}$ and a discussion of thrombolytic therapy to treat pulmonary embolism by Tapson. ${ }^{18}$ These three reviews provide some critical additional specific application narrative to the general conceptual review on novel and emerging therapies for thrombus-targeted fibrinolysis recently published in this journal. ${ }^{19}$

In total, the diversity of reviews presented in the current issue of Seminars in Thrombosis \& Hemostasis reflects the growing understanding of the diversity of normal and pathological processes in which the P-P system plays a role. Given space limitations, certain aspects of the role of the P-P system in diseases have not been presented. For example, there is a growing body of evidence implicating dysregulation of the $\mathrm{P}-$ $\mathrm{P}$ system in various neurodegenerative diseases, including Alzheimer disease. ${ }^{20,21}$ These other functions of the P-P system are also important, and we anticipate that the role of the P-P system in these diseases will continue to be elucidated. To summarize, much has changed in our understanding of the role of the P-P system in normal physiology and diseases since the Seminars in Thrombosis $\mathcal{E}$ Hemostasis issue titled "Cell Biology of Fibrinolysis" in $1991^{3}$ and the field continues to evolve and expand. This should make the next 20 years of Fibrinolysis research and clinical application even more interesting to observe.

\section{References}

1 Hunter J. A Treatise on the Blood, Inflammation, and Gun-Shot Wounds, by the Late John Hunter. To Which is Prefixed, A Short Account of the Author's Life, by His Brother-in-Law, Everard Home. Philadelphia, PA: Thomas Bradford; 1794

2 Morgagni GB. Founders of Modern Medicine: Giovanni Battista Morgagni. (1682-1771). Med Library Hist J 1903;1(4):270-277

3 Kwaan HC, Markus G. Cell biology of fibrinolysis. Tenth International Congress on Fibrinolysis. August 1990. Semin Thromb Hemost 1991;17(3):159-312
4 Miles LA, Parmer RJ. Plasminogen receptors: the first quarter century. Semin Thromb Hemost 2013;39(4):329-337

5 Luo M, Hajjar KA. Annexin A2 system in human biology: cell surface and beyond. Semin Thromb Hemost 2013;39(4): 338-346

6 Ferraris GMS, Sidenius N. Urokinase plasminogen activator receptor: a functional integrator of extracellular proteolysis, cell adhesion, and signal transduction. Semin Thromb Hemost 2013;39(4): 347-355

7 Declerck PJ, Gils A. Three decades of research on plasminogen activator inhibitor-1: a multifaceted serpin. Semin Thromb Hemost 2013;39(4):356-364

8 Vercauteren E, Gils A, Declerck PJ. Thrombin activatable fibrinolysis inhibitor-a putative target to enhance fibrinolysis. Semin Thromb Hemost 2013;39(4):365-372

9 Tucker T, Idell S. Plasminogen-plasmin system in the pathogenesis and treatment of lung and pleural injury. Semin Thromb Hemost 2013;39(4):373-381

10 Kwaan HC, Mazar AP, McMahon BJ. The apparent uPA/PAI-1 paradox in cancer: more than meets the eye. Semin Thromb Hemost 2013;39(4):382-391

11 Gando S. Role of fibrinolysis in sepsis. Semin Thromb Hemost 2013;39(4):392-399

12 Wong RH, Bailes JE. Thrombolysis for intraventricular hemorrhage. Semin Thromb Hemost 2013;39(4):400-405

13 del Zoppo GJ. Plasminogen activators and ischemic stroke: conditions for acute delivery. Semin Thromb Hemost 2013;39(4): 406-425

14 Violi F, Ferro D. Clotting activation and hyperfibrinolysis in cirrhosis: implications for bleeding and thrombosis. Semin Thromb Hemost 2013;39(4):426-433

15 Dhillon PK, Adams MJ. Thrombosis in systemic lupus erythematosus: role of impaired fibrinolysis. Semin Thromb Hemost 2013;39(4):434-440

16 Wicky S, Pinto EG, Oklu R. Catheter-directed thrombolysis of arterial thrombosis. Semin Thromb Hemost 2013;39(4):441-445

17 Oklu R, Wicky S. Catheter-directed thrombolysis of deep venous thrombosis. Semin Thromb Hemost 2013;39(4):446-451

18 Tapson VF. Thrombolytic therapy for acute pulmonary embolism. Semin Thromb Hemost 2013;39(4):452-458

19 Lippi GMC, Mattiuzzi C, Favaloro EJ. Novel and emerging therapies: thrombus-targeted fibrinolysis. Semin Thromb Hemost 2012; 39(1):45-58

20 Archinti M, Britto M, Eden G, Furlan F, Murphy R, Degryse B. The urokinase receptor in the central nervous system. CNS Neurol Disord Drug Targets 2011;10(2):271-294

21 Nalivaeva NN, Fisk LR, Belyaev ND, Turner AJ. Amyloid-degrading enzymes as therapeutic targets in Alzheimer's disease. Curr Alzheimer Res 2008;5(2):212-224 